\author{
Нікішина О.В. \\ доктор економічних наук, старший науковий співробітник \\ відділ ринкових механізмів та структур \\ Інститут проблем ринку та економіко-екологічних досліджень НАН України \\ Французький бульвар, 29, м. Одеса, Україна, 65044 \\ E-mail: ksenkych@gmail.com
}

\title{
МЕТОДИКА АНАЛІЗУ ВАЛОВОЇ ДОДАНОЇ ВАРТОСТІ В МАКРОСИСТЕМАХ
}

Досліджено природу доданої вартості у площині чотирьох наукових підходів (відтворювального, статистичного, бухгалтерського та логістичного) з акцентом на ії соціально-економічні функції. Розроблено методику аналізу валової доданої вартості в макросистемах, орієнтовану на виявлення структурних деформацій у секторальному вимірі, оцінку витратоємності доданої вартості, її впливу на економічну безпеку, місця держави в глобальному ланцюгу вартості для його оптимізації. Головні напрями методики апробовано в ході аналізу динаміки, структури та витратоємності валової доданої вартості секторів національної економіки, результати якого формують аналітичне підґрунтя для ефективних заходів державного впливу.

Ключові слова: валова додана вартість, макросистема, секторальна структура, витратоємність доданої вартості, глобальні ланцюги вартості.

This work is licensed under a Creative Commons Attribution 4.0 International License http://creativecommons.org/licenses/by/4.0/

Постановка проблеми та її зв'язок з важливими науковими та практичними завданнями. Практика прийняття управлінських рішень, обгрунтування напрямів та інструментів державної економічної політики в мінливих умовах глобалізації обумовлює необхідність розвитку діючих та розробки нових методик аналізу макроекономічних показників. Додана вартість (далі - ДВ) характеризує ефективність функціонування економічних систем на мікро-, мезота макрорівнях, дозволяє оцінювати стан і динаміку змін параметрів багаторівневих систем, визначити структурні диспропорції їх розвитку, міжсекторальний і міжринковий розподіл доходів тощо. Показник валової доданої вартості $\epsilon$ одним із головних у національній і міжнародній статистиці. Розвиток методик його аналізу передбачає конструювання інноваційних показників та використання нових методичних прийомів оцінки на базі оновленого методологічного фундаменту оцінки ДВ.

Аналіз останніх публікацій по проблемі. Проблемі методичного забезпечення аналізу доданої вартості в макросистемах присвячені наукові праці Братенкової Т.М. [1], Булиги Р., Кохно П. [2], Гірної О.Б., Глинського Н. Ю. [3], Коваленка О. В. [4], Кондратьєва В. Б. [5], Кравцової І. В. [6], Пєшиної Е. В. [7], Хорунжого М. Й. [8] та інших учених. Проте розробка комплексного методичного підходу до аналізу валової доданої вартості у внутрішньому та зовнішньому вимірах не наявна в роботах даних авторів, що і стало метою нашого дослідження.

Формулювання цілей дослідження. Мета статті - розробка методики аналізу валової ДВ в мак- росистемах та іiі апробація на прикладі деяких секторів національної економіки - окреслила низку завдань:

- визначення природи і методів розрахунку доданої вартості у площині різних наукових підходів;

- обгрунтування оціночної складової методичного підходу;

- аналіз динаміки і структури валової ДВ у внутрішньому та зовнішньому вимірах;

- оцінка показників витратоємності валової ДВ у секторному розрізі;

- контурний аналіз глобальних ланцюгів доданої вартості.

Виклад основних результатів та їх обгрунтування. На підставі досліджень учених [1-11] сутність багатогранної категорії «додана вартість» пропонуємо розкрити з позиції чотирьох підходів: економічного, статистичного, бухгалтерського та логістичного (рис. 1). Кожний із них по-різному інтерпретує природу ДВ та використовує різні методики іiі кількісної оцінки.

Основу економічного підходу формує теорія додатної вартості А. Сміта [9]. Її сутність можна коротко представити в таких твердженнях: (1) нову вартість своєю працею створюють наймані робітники; (2) ця вартість ділиться на дві частини, одну з яких у формі заробітної плати отримують робітники, а іншу в формі прибутку отримує власник капіталу. К. Маркс у праці «Капітал» [10] детально розкрив сутність новоствореної вартості. 


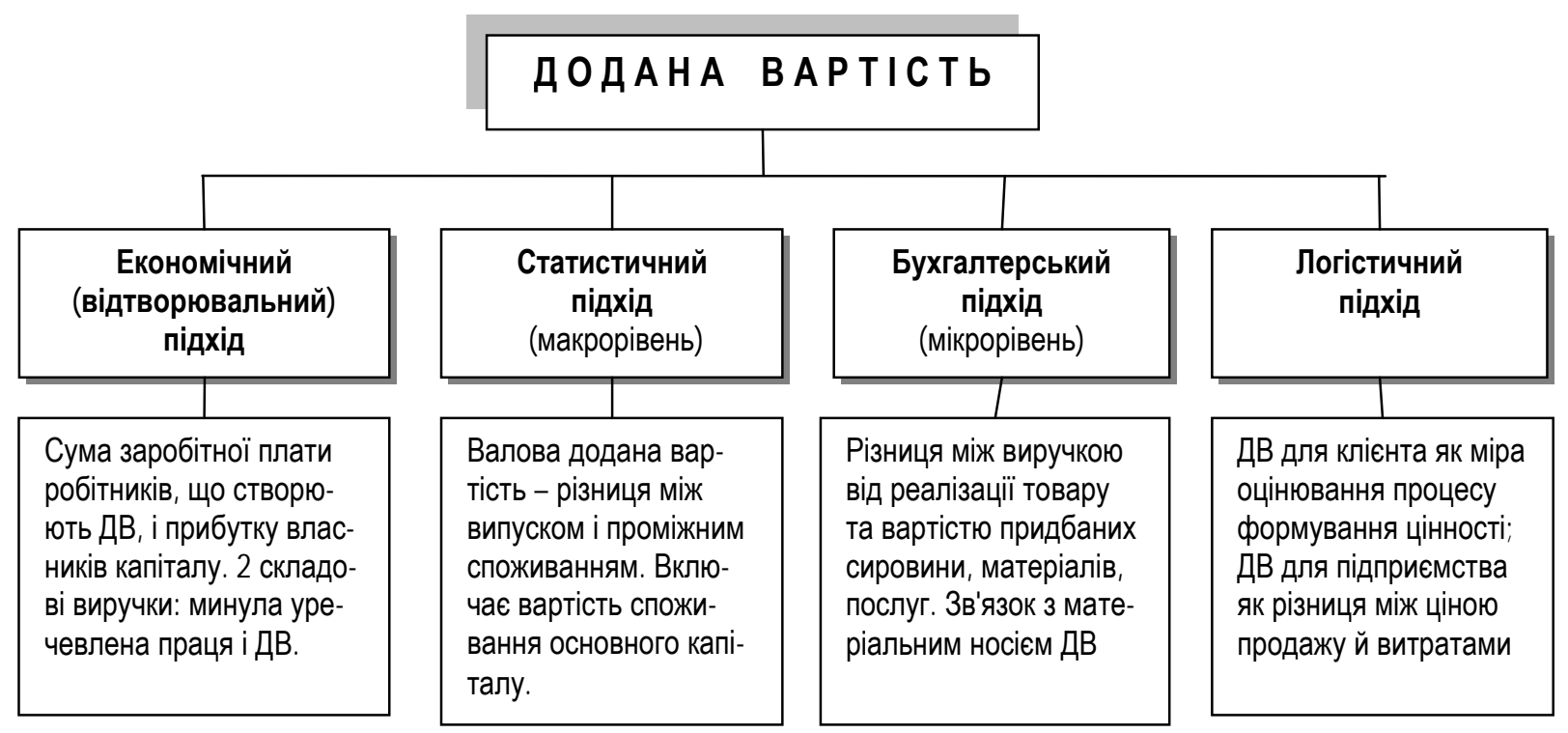

Рис. 1. Множина наукових підходів у трактуванні категорії «додана вартість»* * складено автором із використанням джерел [1-11]

Згідно теорії К. Маркса, виручка підприємства ділиться на три компоненти: уречевлена минула праця, оплата праці робітників та прибуток власників підприємства; останні дві складові формують новостворену вартість. На думку Р. Булиги, К. Маркс вперше побудував алгоритм формування цільового критерію, що охоплює інтереси основних учасників господарської діяльності за одночасного адекватного відображення поточного результату діяльності підприємства. Таким критерієм $є$ новостворена (додана вартість) [2, с. 70]. Сучасні дослідники природи доданої вартості у контексті економічного, або відтворювального підходу розвивали теорію К. Маркса.

Статистичний підхід (див. рис. 1) відображає особливості макроекономічного обліку ДВ на основі системи національних рахунків (СНР). Методика розрахунку валової доданої вартості докладно описана в Методологічних положеннях Держстату і спільних виданнях Євростату з МВФ, Організацією економічного співробітництва та розвитку (далі OECP), ООН та Світового банку. Міжнародна стандартна галузева класифікація всіх видів економічної діяльності визначає валову додану вартість (від англ. Gross Value Addet. GVA) як різницю між вартістю випуску продукції в основних цінах і вартістю проміжного споживання [7, с. 47]. Державна служба статистики України описує валову ДВ як різницю між випуском і проміжним споживанням; вона містить у собі первинні доходи, що створюються учасниками виробництва і розподіляються між ними. При цьому показник валової доданої вартості за видами економічної діяльності розраховується як сума оплати праці найманих працівників, інших податків за виключенням інших субсидій, пов'язаних з виробництвом, та валового прибутку (змішаного доходу) [6, с. 207-209]. Термін «валова» означає, що до складу ДВ входить величина споживання основного капіталу. У трактуванні показників «додана вартість» і «проміжне споживання» в контексті класичної економічної теорії амортизація є елементом останнього [1, с. 14]. Питання включення амортизації необоротних активів до складу ДВ є дискусійним і визначає різні методики іiі розрахунку.

За статистичного підходу СНР ототожнює валову ДВ тільки $з$ доходом, створеним певним видом економічної діяльності в загальному обсязі ВВП, тоді як за бухгалтерського підходу показник доданої вартості оцінюється не тільки з позиції фінансового результату підприємства, але й з точки зору матеріального носія даної величини, тобто конкретного товару. В бухгалтерському обліку ДВ товару розраховується як різниця між виручкою від реалізації товару та вартістю придбаних сировини, матеріалів, послуг на основі даних про собівартість продукції (див. рис. 1). У дослідженнях методика бухгалтерського підходу використовується для аналізу ДВ певних товарів. Вона також може бути використана для оцінки доданої вартості, створеної в секторах ринку, за умови наявності статистичних даних про іï обсяги у розрізі конкретних товарів.

Логістичний підхід додану вартість, створювану окремими ланками ланцюга поставок, поділяє на два типи: ДВ для клієнта і ДВ для підприємства. Головним $є$ клієнтоорієнтований підхід, оскільки саме клієнт $є$ останньою ланкою ланцюга поставок. Дана ланка $\epsilon$ результатом створення цінності на протязі усього ланцюга поставок. В такий спосіб вона стає мірою оцінювання процесу формування цінності, метою якої є пропонування клієнтові відчутної корисності. Додана вартість для підприємства пов'язана із його корисностями, які визначаються різницею між ціною продажу та рівнем понесених витрат. У контексті логістичного підходу підприємство, яке ство- 
рює значну ДВ, сприймається як привабливий суб'єкт господарювання [3, с. 43-44; 11, с. 28-29].

На думку учених $[2,8]$, додана вартість $\epsilon$ критерієм, що оптимально враховує економічні інтереси основних учасників відтворення (підприємств, споживачів та держави). Кожен 3 елементів доданої вартості має своє змістовне навантаження, віддзеркалюючи економічні інтереси певних суб'єктів ринку. Так, фінансовий інтерес бізнесу формують усі складові ДВ, оскільки їх обсяги, співвідношення й характеристики визначають можливість реалізації товару за більш високою ціною для зростання прибутковості підприємства. Інтерес споживачів полягає у можливості придбання якісної продукції за раціональною, якомога нижчою ціною. Держава реалізує свій інтерес у формі позаекономічного, примусового вилучення частини доданої вартості через систему корпоративних податків і податків на доходи фізичних осіб. Економічні інтереси працівників визначаються обсягом та можливістю зростання їх заробітної плати. Відтак, маємо головні функиї складових ДВ: економічну, соціальну та регуляторну.

Окрім перелічених, критерій доданої вартості може виконувати ще одну функцію, не реалізовану в управлінській практиці, а саме: можливість надійно відслідковувати основні результати діяльності підприємств і спрямовувати їх діяльність в необхідне суспільству русло [2, с. 72]. 3 іншого боку, основний результат національної економіки - ВВП - формується на основі показників доданої вартості, що обумовлює необхідність постійного вдосконалення методик iii дослідження та оцінки на базі широкого спектра джерел і факторів створення й перерозподілу ДВ у площині реалізації інтересів держави.

На підставі проведених досліджень нами виділено чотири головні напрями аналізу валової доданої вартості в макросистемах (рис. 2). Перший напрям характеризує динамічні зміни та структурні особливості формування ДВ у секторальному розрізі; другий - iї витратоємність, тобто використання на відтворення основного капіталу, трудових ресурсів, виплату податків; третій - вплив секторної ДВ на зовнішню торгівлю певних товарних груп; четвертий місце держави в глобальному ланцюзі створення вартості. Кожний напрям аналізу передбачає розрахунок відповідних показників та застосування низки методів і прийомів аналізу (див. рис. 2), сукупність яких формує методичний підхід до аналізу валової доданої вартості в макросистемах. Розглянемо його практичні можливості та аналітичні результати більш детально.

\begin{tabular}{|c|c|c|c|}
\hline \multicolumn{4}{|c|}{$\begin{array}{c}\text { Головні напрями аналізу валової доданої вартості (ВДВ) } \\
\text { та система показників (прийомів аналізу) }\end{array}$} \\
\hline \multirow[t]{2}{*}{$\begin{array}{l}\text { 1. Аналіз динаміки і } \\
\text { структури валової } \\
\text { доданої вартості }\end{array}$} & \multicolumn{2}{|c|}{$\begin{array}{l}\text { Внутрішній вимір } \\
\text { Секторальний розріз: сектори } \\
\text { (види економічної діяльності) } \\
\text { національної економіки } \\
\text { Регіональний розріз: регіони } \\
\text { держави (регіональна ДВ) } \\
\end{array}$} & $\begin{array}{l}\text { Показники: } \\
\text { Частка ВДВ сектору в ВВП; динаміка ВДВ сек- } \\
\text { торів; структура ВДВ окремих секторів економі- } \\
\text { ки; динаміка і структура доданої вартості у регі- } \\
\text { ональному розрізі }\end{array}$ \\
\hline & \multicolumn{2}{|c|}{$\begin{array}{l}\text { Зовнішній вимір: } \\
\text { ВДВ різних держав }\end{array}$} & $\begin{array}{l}\text { Динаміка і структура ВДВ за видами економіч- } \\
\text { ної діяльності; зіставлення секторальної струк- } \\
\text { тури ВДВ різних держав }\end{array}$ \\
\hline \multicolumn{2}{|c|}{$\begin{array}{l}\text { 2. Аналіз показників (коефіціє- } \\
\text { нтів) витратоємності валової } \\
\text { доданої вартості }\end{array}$} & $\begin{array}{l}\text { Сектори національної } \\
\text { економіки }\end{array}$ & $\begin{array}{l}\text { Капіталомісткість ВДВ - відношення частки } \\
\text { сектору в інвестиціях до частки сектору в ВДВ } \\
\text { Працемісткість ВДВ }{ }^{* *}-\text { відношення частки } \\
\text { сектору в загальному фонді оплати праці до час- } \\
\text { тки сектору в ВДВ } \\
\text { Податкомісткість ВДВ** }- \text { відношення частки } \\
\text { сектору в податках (за вирахуванням субсидій) } \\
\text { до частки сектору в ВДВ }\end{array}$ \\
\hline \multicolumn{2}{|c|}{$\begin{array}{l}\text { 3. Аналіз впливу ВДВ (у розрізі } \\
\text { секторів) на складові економі- } \\
\text { чної безпеки держави }\end{array}$} & $\begin{array}{l}\text { Зовнішньоекономічна } \\
\text { безпека }\end{array}$ & $\begin{array}{l}\text { Оцінка взаємовпливу динаміки ВДВ сільського } \\
\text { господарства і переробної промисловості та ди- } \\
\text { наміки змін сальдо зовнішньої торгівлі відпові- } \\
\text { дних товарних груп }\end{array}$ \\
\hline \multicolumn{2}{|c|}{$\begin{array}{l}\text { 4. Аналіз глобальних ланцюгів } \\
\text { доданої вартості } \\
\text { (методика ОЕСР) }\end{array}$} & \multicolumn{2}{|c|}{$\begin{array}{l}\text { Індекс участі - сума двох показників: (1) частка вартості, доданої за кор- } \\
\text { доном, в експорті; (2) частка вітчизняної доданої вартості в експорті третіх } \\
\text { країн. } \\
\text { Індекс кількості стадій виробництва - кількість стадій виробничого про- } \\
\text { цесу в глобальному ланцюгу вартості } \\
\text { Індекс відстані до кіниевого попиту - кількість стадій виробництва до кін- } \\
\text { цевого споживача для певної країни (сектору економіки). }\end{array}$} \\
\hline
\end{tabular}

Рис. 2. Оціночна складова методики аналізу валової доданої вартості на макрорівні"

" розроблено автором із використанням джерел $[4,8,6,13,14]$

авторська розробка 
Використовуючи дані макроекономічної статистики, можна розрахувати структуру валової ДВ у секторальному розрізі. Результати таких розрахунків узагальнено в таблиці 1. Аналіз структури валової доданої вартості за секторами національної економіки свідчить про зменшення частки ресурсоутворювальних секторів на фоні зростання питомої ваги торгівлі. Так, частки валової ДВ сільського господарства та переробної промисловості у загальнодержавному ВВП скоротилися, 3 14,41 \% і 17,43\% у 2001 р. до $12,11 \%$ і 11,96\% у 2015 р. відповідно, водночас питома вага ВДВ торгівлі зросла з 10,97 \% до 13,84 \%. В 2015 р. порівняно з 2001 р. обсяги ВДВ торгівлі зросли в 12,2 рази, що значно вище темпів приросту в переробній промисловості та сільському господарстві (див. табл. 1). Учені відзначають [4, с. 99], що протя- гом останніх двадцяти років сукупна частка ДВ сільського господарства й харчової промисловості у структурі валової доданої вартості України знизилася з $23 \%$ до $14 \%$. Стрімке зниження цього показника створює реальну загрозу національній продовольчій безпеці.

У країнах СС питома вага виробничого сектору у валовій ДВ є дещо вищою і складає 22,81\% у Німеччині, 19,69 \% у Польщі, 21,03 \% у Румунії, натомість частка аграрного сектору значно менша, ніж в Україні $(0,64 \%, 2,6 \%$ і 4,76 \% відповідно). Найвищі частки секторів видобутку корисних копалин та виробництва характерні для Китаю $(34,31 \%$ і $27,01 \%)$ та Білорусії $(29,54 \%$ і $25,11 \%$ відповідно); частка аграрного сектору в даних країнах є теж досить високою (9,18\% та 7,55 \% відповідно) [16].

Таблиця 1

Динаміка та структура валової доданої вартості (ВДВ) у секторальному розрізі, млн. грн.*

\begin{tabular}{|c|c|c|c|c|c|c|c|c|c|}
\hline \multirow{2}{*}{ ПОКАЗНИКИ } & \multicolumn{8}{|c|}{ Роки } & \multirow{2}{*}{$\begin{array}{l}2015 \text { p. y \% } \\
\text { до } 2001 \text { р. }\end{array}$} \\
\hline & 2001 & 2005 & 2010 & 2011 & 2012 & 2013 & 2014 & 2015 & \\
\hline $\begin{array}{l}\text { 1. ВДВ сільсь- } \\
\text { кого господар- } \\
\text { ства }\end{array}$ & 29421 & 40542 & 82948 & 109961 & 113245 & 132354 & 161145 & 239806 & у 8,2 рази \\
\hline у\% до ВВП & 14,41 & 9,18 & 7,40 & 8,15 & 7,76 & 8,69 & 10,15 & 12,11 & $X$ \\
\hline $\begin{array}{l}\text { 2. ВДВ переро- } \\
\text { бної промисло- } \\
\text { вості }\end{array}$ & 35592 & 86863 & 146749 & 158738 & 178442 & 169633 & 194050 & 236692 & у 6,7 рази \\
\hline$y \%$ до ВВП & 17,43 & 19,68 & 13,10 & 11,77 & 12,23 & 11,14 & 12,23 & 11,96 & $X$ \\
\hline 3. ВДВ торгівлі & 22409 & 56041 & 162171 & 201746 & 210232 & 222789 & 233702 & 273989 & у 12,2 рази \\
\hline$y \%$ до ВВП & 10,97 & 12,69 & 14,47 & 14,95 & 14,41 & 14,63 & 14,73 & 13,84 & $X$ \\
\hline
\end{tabular}

*розраховано автором за даними Державної служби статистики України $[12,15]$

За статистичними даними, в Україні частка валового прибутку в ДВ виробничого сектору (41 \% в 2015 р.) на $20 \%$ нижча, ніж у торговому $(61,5 \%)$, однак питома вага податкових надходжень від переробних підприємств $(2,8 \%)$ вдвічі перевищує аналогічний показник торгівлі (таблиця 2). Слід відзначити, що істотне зростання валового прибутку виробничого сектору відбулося в 2015 р., у 2011-2012 рр. його значення $(24,8 \%)$ було в 2,3 рази менше питомої ваги прибутку торгового сектору. Учені наголошують, що значна частина доходу від реалізації сільгосппродукції кінцевому споживачеві (особливо від експорту) осідає у торгово-посередницькому секторі й не використовується для розвитку виробництва [4, с. 99].
Аналіз динаміки змін структурних компонентів валової ДВ у секторальному вимірі дозволяє встановити таку тенденцію: темпи приросту частки податків торгового сектору відстають від темпів приросту податкових надходжень аграрного й виробничого секторів, а темпи зниження даної компоненти ДВ в торгівлі є значно нижчими порівняно з ресурсоутворювальними секторами національної економіки (див. табл. 2). Так, у 2015 р. порівняно $з 2014$ р. питома вага податків в аграрному секторі зменшилася на $0,2 \%$, у виробничому - на $0,3 \%$, а в торговому - на $0,5 \%$; у 2012 р. приріст податків у даних секторах склав 0,5, 0,4 і 0,2 \% відповідно.

Таблиця 2

Структура валової доданої вартості секторів національної економіки, \%*

\begin{tabular}{|l|c|c|c|c|c|c|c|c|c|c|}
\hline \multirow{2}{*}{ ПОКАЗНИКИ } & \multicolumn{7}{c|}{ Роки } \\
\cline { 2 - 13 } & 2001 & 2005 & 2008 & 2009 & 2010 & 2011 & 2012 & 2013 & 2014 & 2015 \\
\hline \multicolumn{7}{|c|}{ Аграрний сектор (сільське, лісове господарство, мисливство) } \\
\hline 1. Оплата праці & 19,8 & 17,0 & 22,0 & 21,5 & 21,6 & 20,7 & 23,6 & 23,2 & 19,4 & 14,6 \\
\hline $\begin{array}{l}\text { 2. Податки (за виключен- } \\
\text { ням субсидій) }\end{array}$ & 0,1 & $-2,1$ & $-4,5$ & $-0,4$ & $-0,4$ & $-0,3$ & 0,2 & 0,6 & 0,8 & 0,6 \\
\hline 3. Валовий прибуток & 80,1 & 85,1 & 82,5 & 78,9 & 78,8 & 79,6 & 76,2 & 76,2 & 79,8 & 84,8 \\
\hline
\end{tabular}


Продовження табл.2

\begin{tabular}{|l|c|c|c|c|c|c|c|c|c|c|}
\hline \multirow{2}{*}{ ПОКАЗНИКИ } & \multicolumn{10}{|c|}{ Роки } \\
\cline { 2 - 12 } & 2001 & 2005 & 2008 & 2009 & 2010 & 2011 & 2012 & 2013 & 2014 & 2015 \\
\hline & \multicolumn{1}{|c|}{ 2. Виробничий сектор (переробна промисловість) } \\
\hline 1. Оплата праці & 57,3 & 62,0 & 58,5 & 57,4 & 65,2 & 72,6 & 72,1 & 69,7 & 63,7 & 56,2 \\
\hline $\begin{array}{l}\text { 2. Податки (за виключен- } \\
\text { ням субсидій) }\end{array}$ & 3,5 & 2,8 & $-0,9$ & 0,4 & 1,8 & 2,6 & 3,0 & 3,4 & 3,1 & 2,8 \\
\hline 3. Валовий прибуток & 39,2 & 35,2 & 42,4 & 42,2 & 33,0 & 24,8 & 24,9 & 26,9 & 33,2 & 41,0 \\
\hline & 3. Торговий сектор (оптова та роздрібна торгівля) \\
\hline 1. Оплата праці & 39,9 & 37,3 & 38,2 & 35,8 & 42,1 & 41,9 & 47,5 & 47,3 & 44,0 & 37,0 \\
\hline $\begin{array}{l}\text { 2. Податки (за виключен- } \\
\text { ням субсидій) }\end{array}$ & 6,6 & 2,8 & 2,5 & 2,5 & 2,2 & 1,5 & 1,7 & 2,2 & 1,9 & 1,4 \\
\hline 3. Валовий прибуток & 53,5 & 60,0 & 59,3 & 61,7 & 55,7 & 56,5 & 50,9 & 50,5 & 54,1 & 61,5 \\
\hline
\end{tabular}

*розраховано автором за даними Державної служби статистики України $[12,15]$

Характерною особливістю структури валової доданої вартості виробничого сектора є найвищі значення часток (порівняно з сільським господарством і торгівлею) оплати праці та податкових відрахувань, що свідчить про реалізацію економічних інтересів, передусім, працівників та держави. Відтак, виробничий сектор виконує важливі соціальні й податкові функції в макросистемі, забезпечує відтворення трудового та інтелектуального потенціалів країни, є одним із базових ресурсоутворювальних секторів національної економіки. Розвиток виробничого сектору має стати одним із пріоритетних завдань державної економічної політики, оскільки зростання частки його валової ДВ (наприклад, з $12 \%$ до $20 \%$ - рівень країн ЄC) сприятиме, передусім, збільшенню робочих місць, зростанню заробітної плати та податкових надходжень, що обумовлено структурними особливостями показника в даному секторі.

Багатофункціональність показника валової доданої вартості дозволяє, 3 одного боку, розкрити результативність виробництва та рівень мотивації працівників до продуктивної роботи, з іншого - ступінь оснащеності виробництва, забезпеченість його необхідною технікою, устаткуванням, прогресивними технологіями [4, с. 98]. Для оцінки дієвості аграрної політики професор М. Й. Хорунжий пропонує використовувати коефіцієнт капіталомісткості валової ДВ секторів національної економіки, що розраховується як відношення питомої ваги сектору в інвестиціях до його частки у валовій доданій вартості [8, c. 28]. Ми пропонуємо, поряд 3 показником капіталомісткості, розрахованим за часткою сектору в інвестиціях та вартості основних засобів, використовувати коефіиієнти працемісткості та податкомісткості валової доданої вартості у межах другого напряму запропонованого методичного підходу (див. рис. 2). Група показників витратоємності дозволяє визначити співвідношення між часткою сектору в інвестиціях (фонді оплати праці, податках) та часткою в валовій ДВ і проводити міжсекторальне порівняння за величиною та динамікою змін у часовому розрізі. Результати проведених нами розрахунків показників витратоємності валової доданої вартості у розрізі трьох секторів (аграрного, переробного та торгового) узагальнено в таблиці 3.

Таблиця 3

Динаміка показників витратоємності валової доданої вартості (ВДВ) деяких секторів економіки України, пункти

\begin{tabular}{|c|c|c|c|c|c|c|c|c|c|c|}
\hline \multirow{2}{*}{$\begin{array}{l}\text { Сектори } \\
\text { економіки }\end{array}$} & \multicolumn{10}{|c|}{ Роки } \\
\hline & 2001 & 2005 & 2008 & 2009 & 2010 & 2011 & 2012 & 2013 & 2014 & 2015 \\
\hline \multicolumn{11}{|c|}{ Капіталомісткість ВДВ (за вартістю основних засобів) } \\
\hline $\begin{array}{l}\text { 1.Сільське господарс- } \\
\text { тво }\end{array}$ & 0,708 & 0,649 & 0,443 & 0,367 & 0,230 & 0,196 & 0,194 & 0,173 & 0,123 & н.Д. \\
\hline 2. Промисловість & 1,254 & 1,323 & 0,923 & 1,060 & 0,740 & 0,692 & 0,816 & 0,845 & 0,688 & н.д. \\
\hline в т.ч. переробна & 1,091 & 0,979 & 0,802 & 1,014 & 0,810 & 0,741 & 0,606 & 0,518 & 0,450 & н.д. \\
\hline 3. Торгівля & 0,202 & 0,226 & 0,204 & 0,178 & 0,110 & 0,112 & 0,105 & 0,081 & 0,062 & н.д. \\
\hline \multicolumn{11}{|c|}{ Капіталомісткість ВДВ (за інвестиціями в основний капітал) } \\
\hline $\begin{array}{l}\text { 1.Сільське господарс- } \\
\text { тво }\end{array}$ & 0,345 & 0,587 & 1,055 & 0,859 & 0,827 & 0,804 & 0,852 & 0,819 & 0,844 & 0,911 \\
\hline 2. Промисловість & 1,546 & 1,391 & 1,257 & 1,619 & 1,341 & 1,573 & 1,639 & 1,981 & 1,918 & 1,616 \\
\hline 3. Торгівля & 0,359 & 0,644 & 0,765 & 0,652 & 0,690 & 0,628 & 0,586 & 0,571 & 0,641 & 0,547 \\
\hline
\end{tabular}


Продовження табл.3

\begin{tabular}{|c|c|c|c|c|c|c|c|c|c|c|}
\hline \multirow{2}{*}{$\begin{array}{l}\text { Сектори } \\
\text { економіки }\end{array}$} & \multicolumn{10}{|c|}{ Роки } \\
\hline & 2001 & 2005 & 2008 & 2009 & 2010 & 2011 & 2012 & 2013 & 2014 & 2015 \\
\hline \multicolumn{11}{|c|}{ Працемісткість ВДВ } \\
\hline $\begin{array}{l}\text { 1.Сільське господарс- } \\
\text { тво }\end{array}$ & 0,468 & 0,346 & 0,443 & 0,435 & 0,447 & 0,438 & 0,468 & 0,463 & 0,419 & 0,372 \\
\hline $\begin{array}{l}\text { 2. Переробна промис- } \\
\text { ловість }\end{array}$ & 1,354 & 1,264 & 1,180 & 1,162 & 1,351 & 1,538 & 1,429 & 1,392 & 1,376 & 1,428 \\
\hline 3. Торгівля & 0,943 & 0,759 & 0,769 & 0,724 & 0,873 & 0,888 & 0,940 & 0,944 & 0,949 & 0,941 \\
\hline \multicolumn{11}{|c|}{ Податкомісткість ВДВ } \\
\hline $\begin{array}{l}\text { 1.Сільське господарс- } \\
\text { тво }\end{array}$ & 0,006 & $-0,163$ & $-0,365$ & $-0,030$ & $-0,031$ & $-0,020$ & 0,012 & 0,044 & 0,065 & 0,035 \\
\hline $\begin{array}{l}\text { 2. Переробна промис- } \\
\text { ловість }\end{array}$ & 0,261 & 0,220 & $-0,074$ & 0,031 & 0,157 & 0,190 & 0,237 & 0,270 & 0,242 & 0,169 \\
\hline 3. Торгівля & 0,497 & 0,217 & 0,202 & 0,198 & 0,184 & 0,112 & 0,131 & 0,173 & 0,147 & 0,088 \\
\hline
\end{tabular}

*розраховано автором за даними Державної служби статистики України $[12,15]$

Динаміка коефіцієнта капіталомісткості валової ДВ (за вартістю основних засобів) має знижувальний тренд: у 2014 р. порівняно з 2001 р. для сільського господарства та промисловості показник скоротився на 0,6 пункти, для торгівлі - на 0,14 пункти, що $є$ наслідком вищої частки секторів у доданій вартості порівняно з їх питомою вагою в вартості основних засобів (див. табл. 3). Навпаки, динаміка коефіцієнта капіталомісткості (за інвестиціями в основний капітал) має зростаючий тренд: у 2015 р. порівняно 3 2001 р. показник зріс на 0,57 пункти для аграрного, на 0,07 пункти - для промислового й на 0,19 пункти для торговельного сектору, що обумовлено динамікою змін часток даних секторів в інвестиціях. Загалом найвищі значення двох показників капіталомісткості характерні для промисловості (0,688 і 1,616 пункти), водночас їх динаміку в першому випадку описує подвійне зниження, в другому - повільне зростання (всього 0,07 пункти).

Коефіцієнт працемісткості дозволяє співставити питому вагу сектору в загальному фонді оплати праці й частку сектору в валовій ДВ. За 2001-2015 pр. значення даного показника в сільському господарстві та торгівлі скоротилося на 0,1 і 0,002 пункти й склало 0,372 і 0,941 пункти відповідно, в переробній промисловості, навпаки, зросло на 0,07 пункти й досягло 1,428 пункти в звітному періоді (див. табл. 3). У 2015 р. частка переробної промисловості в фонді заробітної плати складала $17,08 \%$ (на 6,5 \% менше рівня 2001 р.), у валовій ДВ - 11,96 \% (на 5,5\% менше рівня 2001 р.), що забезпечило найвище значення коефіцієнта працемісткості та незначну динаміку його зростання.

Серед усіх показників витратоємності валової доданої вартості коефіцієнт податкоємності має найнижчі значення (див. табл. 3): 0,035 пункти для сільського господарства, 0,169 пункти для переробної промисловості й 0,088 пункти для торгівлі, що обумовлено значно нижчими частками даних секторів у загальних податкових надходженнях $(0,43,2,02$ i $1,22 \%$ відповідно) порівняно 3 їх питомою вагою в валовій ДВ. У 2015 р. порівняно з 2001 р. показник податкоємності для аграрного сектору зріс на 0,03 пункти, що пов'язано зі скороченням обсягів його субсидування, для переробного й торговельного секторів він зменшився на 0,09 і 0,41 пункти відповідно. Загалом найвищі значення коефіцієнтів витратоємності притаманні переробній промисловості, що відображає структурну архітектуру валової доданої вартості даного сектору (див. табл. 1) і є свідченням достатнього рівня (порівняно 3 іншими секторами) реінвестування ДВ у процес відтворення як механізму iї зростання в наступному відтворювальному циклі.

Третій напрям методичного підходу пов'язаний з аналізом впливу валової ДВ (у розрізі секторів) на компоненти економічної безпеки держави (див. рис. 2). У працях українських вчених підкреслюється особливий взаємозв'язок валової доданої вартості 3 національною продовольчою безпекою, зокрема, як чинника ціноутворення й джерела формування ВВП [4, с. 98]. 3 іншого боку, просліджується ії зв'язок із зовнішньоекономічною безпекою, рівень якої знижується через домінуючий сировинний вектор українського агроекспорту. Методичні підходи до аналізу взаємовпливу ДВ і складових національної економічної безпеки детально описані автором у праці [17].

Четвертий напрям методичного підходу, що пропонується, пов'язаний з аналізом глобальних ланцюгів доданої вартості (див. рис. 2). Концепція глобальних товарних ланцюжків, що виникла в 1970 р., у 2000 р. трансформувалася в концепцію глобальних ланцюгів ДВ [5]. Глобальний ланцюг створення вартості - це послідовність взаємопов'язаних видів діяльності зі створення доданої вартості, розташованих як мінімум на двох континентах або в межах двох торгових блоків, що забезпечують виробництво товару або послуги, починаючи з ідеї щодо їх створення та закінчуючи доставкою до кінцевого споживача [13, c. 4]. За критерієм розподілу ринкової сили і спрямованістю інформаційних потоків ланцюги створення вартості поділяють на «мотивовані виробником» (produser-drivent) і «мотивовані покупцем» (buyerdrivent). «Мотивовані виробником» ланцюги ДВ 
створюються у високотехнологічних секторах (виробництві напівпровідників, електроніки, автомобільній та фармацевтичній промисловості), де і спостерігається найвища фрагментація виробничого процесу. «Мотивовані покупием» ланцюги ДВ формуються навколо великих підприємств роздрібної торгівлі, які зосереджують діяльність на маркетингу й продажах не капіталомістких товарів (одягу, взуття, іграшок тощо) $[6,5]$.

Концепція глобальних ланцюгів ДВ дала поштовх розвитку нових підходів до збирання світової торгової статистики. Показник частки вертикальної спеціалізації (імпортної складової експорту), що розраховується на базі національних таблиць «витративипуск», не дозволяє повністю оцінити ланцюги ДВ, оскільки імпорт може включати вартість, додану в національній економіці. Тому ОЕСР спільно зі Світовою організацією торгівлі розробили нову базу даних «Торгівля в доданій вартості» (The Trade in Value Added (TiVA)) на основі глобальних моделей міжнародного виробництва й торгових мереж. У базі TiVA інформація спрямована на об'єктивне відстеження глобальних виробничих мереж і ланцюгів постачань. Індикатори ланцюгів глобальної вартості ОЕСР представлені для 59 країн і 18 секторів економіки за 5 ро- ків (1995, 2000, 2005, 2008 і 2009). Зазначені показники розраховуються на основі п'яти глобальних матриць TiVA [18].

Iндекс участі (Participation index), запропонований Р. Купменом в 2010 р., розраховується як сума частки вартості, доданої за кордоном, в експорті, та частки вітчизняної ДВ в експорті третіх країн (див. рис. 2). Динаміка індексу участі деяких країн у глобальних ланцюгах вартості наведена в таблиці 4. У 2009 р. порівняно 32000 р. індекс участі зріс за всіма країнами (окрім США та Південної Африки). У звітному періоді найвищі значення індикатора притаманні Швеції та Гонконгу (55,7 і 55,8 \%), найменші Євросоюзу та США (30,2 і 39,8 \% відповідно). Малі відкриті економіки, такі як Південна Корея, Фінляндія, Швеція, при виробництві експортних товарів використовують більше іноземних проміжних ресурсів і $\epsilon$ більш залученими до участі в глобальних ланцюгах ДВ, ніж великі економіки, такі як США, СС та Японія, в яких через розмір економіки значна частина ланцюгів вартості зосереджена на власній території. У випадку великих економік доцільно аналізувати дві складові індексу участі; як правило, його високе значення обумовлено значною часткою ДВ в експорті третіх країн $[6,5]$.

Таблиця 4

Індекси участі країн, кількості стадій виробництва та відстані до кінцевого попиту*

\begin{tabular}{|c|c|c|c|c|c|}
\hline \multirow{2}{*}{ Країни } & \multicolumn{4}{|c|}{ Роки } & \multirow{2}{*}{ Динаміка змін (+, -) } \\
\hline & 2000 & 2005 & 2008 & 2009 & \\
\hline \multicolumn{6}{|c|}{ Індекс участі (Participation index), \% } \\
\hline 1.Свропейський Союз & 29,8 & 32,8 & 33,2 & 30,2 & 0,4 \\
\hline 2.Німеччина & 48,8 & 50,7 & 51,9 & 49,5 & 0,7 \\
\hline 3.Швеція & 54,8 & 56,7 & 58,5 & 55,7 & 0,9 \\
\hline 4.Японія & 36,0 & 43,4 & 50,1 & 47,7 & 11,7 \\
\hline 5. США & 40,2 & 43,4 & 44,3 & 39,8 & $-0,4$ \\
\hline 6.Китай & 32,6 & 48,6 & 47,6 & 46,1 & 13,5 \\
\hline 7. Гонконг, Китай & 50,5 & 56,2 & 58,1 & 55,8 & 5,3 \\
\hline 8.Південна Африка & 48,1 & 32,7 & 36,9 & 33,8 & $-14,3$ \\
\hline 9. Росія & 51,3 & 57,5 & 58,4 & 51,8 & 0,5 \\
\hline 10. Інший світ & 40,3 & 45,8 & 49,7 & 45,7 & 5,4 \\
\hline \multicolumn{6}{|c|}{ Індекс кількості стадій виробництва (Index of the number of production stages) } \\
\hline 1.Свропейський Союз & 1,81 & 1,81 & 1,85 & 1,82 & 0,01 \\
\hline 2.Німеччина & 1,73 & 1,75 & 1,81 & 1,76 & 0,04 \\
\hline 3.Швеція & 1,81 & 1,82 & 1,89 & 1,85 & 0,04 \\
\hline 4.Японія & 1,80 & 1,82 & 1,89 & 1,80 & 0,01 \\
\hline 5. США & 1,74 & 1,71 & 1,70 & 1,63 & $-0,10$ \\
\hline 6.Китай & 2,43 & 2,56 & 2,54 & 2,54 & 0,12 \\
\hline 7. Гонконг, Китай & 2,05 & 2,20 & 2,10 & 2,11 & 0,07 \\
\hline 8.Південна Африка & 1,74 & 1,99 & 1,97 & 1,98 & 0,24 \\
\hline 9. Росія & 1,67 & 1,70 & 1,72 & 1,75 & 0,08 \\
\hline 10. Інший світ & 1,82 & 1,80 & 1,74 & 1,75 & $-0,07$ \\
\hline
\end{tabular}


Продовження табл.4

\begin{tabular}{|c|c|c|c|c|c|}
\hline \multirow{2}{*}{ Країни } & \multicolumn{4}{|c|}{ Роки } & \multirow{2}{*}{$\begin{array}{c}\text { Динаміка змін (+, - } \\
\text { ) }\end{array}$} \\
\hline & 2000 & 2005 & 2008 & 2009 & \\
\hline \multicolumn{6}{|c|}{ Індекс відстані до кінцевого попиту ( Index of distance to final demand) } \\
\hline 1.Свропейський Союз & 1,85 & 1,84 & 1,88 & 1,86 & 0,01 \\
\hline 2.Німеччина & 1,79 & 1,84 & 1,95 & 1,90 & 0,10 \\
\hline 3.Швеція & 1,93 & 1,93 & 1,97 & 1,92 & $-0,01$ \\
\hline 4.Японія & 1,84 & 1,87 & 1,91 & 1,84 & 0,00 \\
\hline 5. США & 1,73 & 1,69 & 1,68 & 1,64 & $-0,08$ \\
\hline 6.Китай & 2,42 & 2,60 & 2,66 & 2,67 & 0,25 \\
\hline 7. Гонконг, Китай & 2,01 & 2,23 & 2,10 & 2,12 & 0,11 \\
\hline 8.Південна Африка & 1,99 & 1,98 & 1,94 & 1,99 & 0,00 \\
\hline 9. Росія & 2,29 & 2,26 & 2,20 & 2,16 & $-0,12$ \\
\hline 10. Інший світ & 2,20 & 2,23 & 2,19 & 2,10 & $-0,10$ \\
\hline
\end{tabular}

*складено автором за даними статистики ОЕСР [18]

Індекс кількості стадій виробництва (Index of the number of production stages), запропонований Т. Фоллі в 2012 р. [14], відображає кількість виробничих стадій у глобальному ланцюзі вартості. Мінімальне значення індексу складає 1 , коли для виробництва кінцевого продукту зовсім не використовуються проміжні товари або послуги. Динаміка індексу кількості стадій виробництва засвідчує його зростання в 2009 р. порівняно 32000 р. за всіма країнами, окрім США (див. табл. 4). У період між 2000 р. і 2008 р. спостерігається тенденція зростання довжини глобальних ланцюгів, яка 3 настанням фінансової кризи змінюється на протилежну, що зумовлено проблемами фінансування і зростанням транзакцій них витрат внаслідок невизначеності поставок сировини і матеріалів. В 2009 р. найвище значення індикатора притаманне Китаю $(2,54)$, найменше -США $(1,63)$. До секторів 3 найбільшою фрагментацією належать виробництво транспортного обладнання, тканин й одягу, металовиробів, електричного й оптичного обладнання, машинобудування; у цих секторах кількість стадій виробництва коливається між 2,5 і 2,8. Найменшу довжину ланцюгів ДВ мають сектор послуг, видобувна промисловість і сільське господарство; індекс кількості стадій виробництва варіює від 1,5 до 1,8 [18].

Індекс відстані до кінцевого попиту (Index of distance to final demand), запропонований Т. Фоллі в 2012 р. [14], показує, скільки для певної галузі країни залишилося стадій виробництва, перш ніж товар (послуга) досягне кінцевого споживання. Відповідно, вищі значення індикатора характерні для країн та секторів, які розташовані на початку глобальних ланцюгів ДВ (дослідження і розробка продукту, постачання сировини), а нижчі - для тих ланок, які спеціалізуються на дистрибуції, маркетингу, продажах [6, c. 43]. Динаміка індексу відстані до кінцевого попиту засвідчує його зростання в 2009 р. порівняно з 2000 р. за всіма країнами, окрім Швеції та США (див. табл. 4). У період між 2000 р. і 2008 р. спостерігається тенденція зростання індикатора, у 2009 р. - тенденція його зниження за всіма країнами, окрім Китаю та Пі- вденної Африки. У 2009 р. найвище значення показника притаманне Китаю $(2,67)$ і Росії $(2,16)$, найнижче - США $(1,64)$ і Японії $(1,84)$. Загалом у країнах, що розвиваються, відстань до кінцевого споживача істотно більша, ніж у розвинених, що свідчить про їх переважаючу спеціалізацію на виробництві первинних або проміжних товарів [5].

Таким чином, аналіз глобальних ланцюгів доданої вартості дозволяє визначити місце і роль окремих держав у глобальному виробничому процесі, а також обгрунтувати напрями економічної стратегії країни, іï торговельної, інвестиційної політики тощо. Об'єктивний вимір транснаціоналізації із використанням показника ДВ необхідний для реалізації стимулів залучення країни у міжнародні ланцюги вартості, ефективне використання ресурсів та ії інтеграцію в світовий простір із захистом національної економічної системи.

Висновки та перспективи подальших досліджень. Визначено природу доданої вартості у площині чотирьох наукових підходів 3 акцентом на статистичний і логістичний підходи до їі аналізу в макросистемах. Обгрунтовано, що кожен із компонентів ДВ відображає економічні інтереси основних учасників процесу відтворення, виконуючи низку важливих функцій: економічну, соціальну, регуляторну та оціночну. Запропонована автором методика аналізу валової доданої вартості об'єднала в єдину методичну площину чотири напрями аналізу та систему показників, як широко вживаних, так й інноваційних, зокрема, коефіцієнти капіталомісткості, працемісткості та податкомісткості валової ДВ, що розраховуються за секторами національної економіки. Головна ідея методики аналізу ДВ у макросистемах полягає у визначенні структурних деформацій та рівня витратоємності доданої вартості в секторальному вимірі, в оцінці її впливу на економічну безпеку держави, місця країни в глобальному ланцюзі вартості в контексті його оптимізації.

Головні напрями методики апробовані в ході аналізу динаміки і структури валової доданої вартості, а також їі витратоємності в розрізі трьох секторів 
національної економіки - аграрного, переробного та торгового, що дозволило визначити низку структурних особливостей, деформацій і співвідношень, які можуть бути враховані в ході розробки державної регуляторної політики в секторальному розрізі. Показано практичні можливості показника ДВ для ефективного виміру процесів транснаціоналізації економіки. Аналіз зовнішніх товарно-фінансових потоків за доданою вартістю дозволяє визначити сектори створення робочих місць, переваги або недоліки торгівлі для країн-учасниць глобального ланцюга вартості. Даний методичний підхід дозволяє відстежувати усі зв'язки між різними ланками географічно фрагментованого міжнародного виробництва, визначати роль кожного учасника та прогнозувати наслідки для певної держави, що свідчить про його високу прикладну значимість.
Наукова новизна проведеного дослідження полягає в удосконаленні теоретико-методичних положень щодо аналізу ДВ в макросистемах, які базуються на багатовимірній інтерпретації природи новоствореної вартості 3 акцентом на іiі соціальноекономічні функції, розширеній оціночній основі 3 використанням системи прикладних показників, у т.ч. інноваційних (коефіцієнти витратоємності валової доданої вартості), що дозволяють визначати глибинні структурні деформації секторальної ДВ та будувати механізми управління нею за всіма ланками відтворювального ланцюга. Наближення запропонованої методики аналізу валової доданої вартості в макросистемах до практичного застосування державними органами влади та суб'єктами господарювання формує перспективу подальших досліджень.

\section{Література}

1. Братенкова Т. М. Методические подходы к определению добавленной стоимости в аспекте измерения регионального продукта / Т. М. Братенкова // Труды БГТУ. - 2013. - №7. - С.13-15.

2. Булыга Р. Добавленная стоимость как целевой критерий /Р. Булыга, П. Кохно // Экономист. - 2007. - №10. - С. $68-76$.

3. Гірна О. Б. Формування доданої вартості для клієнта в ланцюгу поставок / О. Б. Гірна, Н. Ю. Глинський, О. Я. Кобилюх // Логістика: теорія та практика. - 2012. - № 1(2). - С. 39-46.

4. Коваленко О.В. Додана вартість у контексті національної продовольчої безпеки / О.В.Коваленко // Економіка та держава. - 2015. - №4. - С. 98 - 102.

5. Кондратьев В. Б. Глобальные цепочки добавленной стоимости в современной экономике. [Электронный ресурс]. - Режим доступа: http://www.perspektivy.info/rus/gos/

6. Кравцова I. В. Методика дослідження глобальних ланцюгів створення вартості / I. В. Кравцова // Науковий вісник Міжнародного гуманітарного університету: зб. наук. праць. - Одеса, 2016. - Вип. 16. - С. 3944.

7. Пешина Э. В. Формирование валовой добавленной стоимости высокотехнологичной и наукоемной продукции (товаров, услуг) / С. В. Пешина, П. А. Авдеев // Известия УрГСУ. - 2013. - №6(50). - С. 46-56.

8. Хорунжий М. Й. Завдання національної аграрної політики на сучасному етапі / М. Й. Хорунжий // Економіка АПК. - 2014. - № 2. - С. 22-29.

9. Сміт А. Добробут націй. Дослідження про природу та причин добробуту націй / А. Сміт; пер. 3 англ. - K.:Port-Royal, 2001. - 366 c.

10. Маркс К. Капитал. Критика политической экономии / К.Маркс ; под. ред. Ф.Энгельса; пер. И.И.Скворцова-Степанова. - Т.1. - М.:Изд-во полит. лит-ры, 1978. - 648 с.

11. Ciesielski M. Zarzadzanie lancuchami dostaw. Pod red. naukowa M. Ciesielskiego / M. Ciesielski, J. Dlugosz, K. Fuks i in. - Warszava: PWE, 2011. - 190 s.

12. Статистичний щорічник України за 2015 рік / За ред. І. М. Жук. - К.: Державна служба статистики України, 2016. - 574 с.

13. Gereffi G. Global Value Analysis: A Primer / G. Gereffi, K. Fernandez-Stark. - Durham: Centeron Globalization, Governance\&Competitivess, Duke University, 2011. - 40p.

14. Fally T. On the Fragmentation of Production in the US / T. Fally. - University of Colorado- Boulder: Mimeo, 2011. -49 p.

15. Офіційний сайт Державної служби статистики України. [Електронний ресурс] - Режим доступу: //http://www.ukrstat.gov.ua/

16. Data of subdivision UN Statistics. National accounts main agregates database. (2017). Retrieved from http://unstats.un.org/unsd/snaama/selbasicFast.asp

17. Нікішина О.В. Інтегрований зерновий ринок у забезпеченні економічної безпеки держави /

О. В. Нікішина // Економіка харчової промисловості. - 2015. - Т.7, № 4. - С. 9-20.

18. OECD Global Value Chains Indicators. (2017). Retrieved from http://stats.oecd.org/Index.aspx?Queryid=53257\#. 


\author{
Никишина О.В. \\ доктор экономических наук, старший научный сотрудник \\ отдел рыночных механизмов и структур \\ Институт проблем рынка и экономико-экологических исследований НАН Украины \\ Французский бульвар, 29, г. Одесса, Украина, 65044 \\ E-mail: ksenkych@gmail.com
}

\title{
МЕТОДИКА АНАЛИЗА ВАЛОВОЙ ДОБАВЛЕННОЙ СТОИМОСТИ В МАКРОСИСТЕМАХ
}

В статье раскрыта природа категории «добавленная стоимость» с позиции четырех подходов: воспроизводственного, статистического, бухгалтерского и логистического. Обоснованно функции компонентов добавленной стоимости, а именно: экономическую, социальную, регуляторную и оценочную. Разработана методика анализа валовой добавленной стоимости в макросистемах, которая объединила четыре направления: (1) анализ динамики и структуры добавленной стоимости во внутреннем и внешнем измерениях; (2) анализ показателей расходоемкости валовой добавленной стоимости; (3) анализ влияния добавленной стоимости на составляющие экономической безопасности государства, в частности, на продовольственную и внешнеэкономическую безопасность; (4) анализ глобальных цепочек добавленной стоимости.

Главная идея методики, предложенной автором, состоит в определении деформаций в структуре валовой добавленной стоимости различных секторов экономики, в оценке уровня и динамики показателей расходоемкости - капиталоемкости, трудоемкости и налогоемкости добавленной стоимости в секторальном измерении, места страны в глобальной цепочке стоимости для ее оптимизации.

Главные направления методики апробированы в ходе анализа валовой добавленной стоимости аграрного, перерабатывающего и торгового секторов украинской экономики, что позволило определить ряд структурных особенностей и соотношений. Так, характерной особенностью структуры валовой добавленной стоимости производственного сектора являются высокие значения долей (по сравнению с сельским хозяйством и торговлей) оплаты труда и налоговых поступлений, что свидетельствует о реализации экономических интересов, прежде всего, работников и государства. Высокие значения коэфрфрициентов расходоемкости присущи также производственному сектору, что является свидетельством достаточного уровня (по сравнению с другими секторами) реинвестирования добавленной стоимости в процесс воспроизводства как механизма ее роста в следующем воспроизводственном цикле. Результаты анализа показывают, что развитие производственного сектора должно стать одной из приоритетных задач государственной экономической политики, поскольку рост доли его валовой добавленной стоимости (например, с 12 \% до $20 \%$ - уровень стран ЕС) будет способствовать увеличению рабочих мест, росту заработной платы и налоговых поступлений.

Ключевые слова: валовая добавленная стоимость, макросистема, секторальная структура, расходоемкость добавленной стоимости, глобальные цепочки стоимости.

\author{
Nikishina 0. \\ Doctor of Economics, Senior Researcher \\ Department of market mechanisms and structures \\ Institute of market problems and economic \& ecological research \\ of National Academy of Sciences of Ukraine \\ Frantsuzskiy boulevard, 29, Odessa, Ukraine, 65044 \\ E-mail: ksenkych@gmail.com

\section{METHODS OF ANALYZING GROSS VALUE ADDED IN MACROSYSTEMS}

The article describes the nature of category "added value» from a position of four approaches: reproduction, statistical, accounting and logistics. The functions of components of added value are justified, namely: economic, social, regulatory and evaluation. The methods of analyzing gross value added in macrosystems, which united four directions have been developed: (1) analysis of dynamics and structure of value added in the internal and external dimensions; (2) analysis of indicators of expenses intensity of the gross value added; (3) analysis of the impact of value added on components of economic security of the state, in particular, on food and foreign economic security; (4) analysis of global chains of the value added. 
The main idea of the methods, proposed by the author, consists in determination of deformations in structure of gross value added of various sectors of economics, in assessing the level and dynamics of indicators of expenses intensity - capital intensity, labor intensity and tax intensity of the value added in sector dimension, of the country place in global chain of the value for its optimization.

The main directions of methods have been tested during the analysis of gross value added of agrarian, processing and trading sectors of the Ukrainian economy, which allowed to identify a number of structural features and relationships. For example, the characteristic feature of structure of gross value added of the industrial sector is high value of proportions (compared to agriculture and trade) of wages and tax revenues, and it testifies to realization of economic interests, first of all, of workers and the state. The high value expenses intensity coefficients are also inherent in an industrial sector, which is evidence of the sufficient level (compared to other sectors) of reinvestment of value added in the process of reproduction as a mechanism for its growth in next reproduction cycle. The results of the analysis prove, that development of the industrial sector should be a priority task of state economic policy, since the increase in proportion of its gross value added (for example, from $12 \%$ to $20 \%$ - level of the EU countries) will promote an increase of jobs, increase of wages and tax revenues.

Keywords: gross value added, macrosystem, sectoral structure, expenses intensity of value added, global chains of value.

\section{References}

1. Bratenkova, T. M. " Metodycheskye podkhodы k opredelenyiu dobavlennoi stoymosty v aspekte yzmerenyia rehyonalnoho produkta." Trudы BHTU 7 (2013): 13-15.

2. Bulbha, R. (2007). Dobavlennaia stoymost kak tselevoi kryteryi . Эkonomyst, 10, 68-76.

3. Hirna, O. B. (2012). Formuvannia dodanoi vartosti dlia kliienta v lantsiuhu postavok. Lohistyka: teoriia ta praktyka, 1(2), 39-46.I

4. Kovalenko , O. V. (2015). Dodana vartist u konteksti natsionalnoi prodovolchoi bezpeky. Ekonomika ta derzhava, 4, 98-102.

5. Kondratev , V. B.. Hlobalnыe tsepochky dobavlennoi stoymosty v sovremennoi эkonomyke. Retrieved May 11, 2017, from http://www.perspektivy.info/rus/gos/

6. Kravtsova , I. V. (2016). Metodyka doslidzhennia hlobalnykh lantsiuhiv stvorennia vartosti . Naukovyi visnyk Mizhnarodnoho humanitarnoho universytetu: zb. nauk. prats, 16, 39-44.

7. Peshyna, E. V. (2013). Formyrovanye valovoi dobavlennoi stoymosty vыsokotekhnolohychnoi у naukoemnoi produktsyy (tovarov, usluh). Yzvestyia UrHIeU, 6(50), 46-56.

8. Khorunzhyi, M. I. (2014). Zavdannia natsionalnoi ahrarnoi polityky na suchasnomu etapi . Ekonomika APK, 2, 22-29.

9. Smit, A. (2001). Dobrobut natsii. Doslidzhennia pro pryrodu ta prychyn dobrobutu natsii. K.: Port-Royal.

10. Marks , K. (1978). Kapytal. Krytyka polytycheskoi эkonomyy (T.1). M.: Yzd-vo polyt. lyt-rb.

11. Ciesielski , M. (2011). Zarzadzanie lancuchami dostaw. Warsawa: PWE.

12.Zhuk, I. M. (2016). Statystychnyi shchorichnyk Ukrainy za 2015 rik. K.: Derzhavna sluzhba statystyky Ukrainy.

13. Gereffi G. (2011). Global Value Analysis: A Primer. Durham: Centeron Global-ization, Governance\&Competitivess, Duke University.

14. Fally T. (2011). On the Fragmentation of Production in the US. University of Colorado- Boulder: Mimeo.

15. Ofitsiinyi sait Derzhavnoi sluzhby statystyky Ukrainy. Retrieved March 11, 2017, from Rezhym dostupu: //http://www.ukrstat.gov.ua/

16. Data of subdivision UN Statistics. National accounts main agregates database. (2017). Retrieved from http://unstats.un.org/unsd/snaama/selbasicFast.asp

17. Nikishyna, O. V. (2015). Intehrovanyi zernovyi rynok u zabezpechenni ekonomichnoi bezpeky derzhavy . Ekonomika kharchovoi promyslovosti, 4(7), 9-20.

18. OECD Global Value Chains Indicators. (2017). Retrieved from http://stats.oecd.org/Index.aspx?Queryid=53257\#. 